\title{
SWARMING AND MIGRATION \\ OF APIS DORSATA AND APIS LABORIOSA HONEY BEES IN INDIA, NEPAL AND BHUTAN
}

\author{
Jerzy Woyke ${ }^{1}$, Jerzy Wilde ${ }^{2}$, Maria Wilde ${ }^{3}$ \\ ${ }^{1}$ Division of Apiculture, Warsaw University of Life Science, \\ 166 Nowoursynowska, 02-787 Warsaw, Poland, \\ ${ }^{2}$ Apiculture Division University of Warmia and Mazury \\ in Olsztyn, 48 Słoneczna, 10-957 Olsztyn, Poland \\ ${ }^{3}$ Honeybee Breeding Centre, Gryźliny, 11-034 Stawiguda, Poland \\ e-mail: jerzy_woyke@sggw.pl
}

Received 26 November 2011; accepted 29 February 2012

$\mathrm{S}$ u m m a r y

The migratory open air nesting Apis dorsata and Apis laboriosa honeybees migrate at least twice a year. DNA genotyping showed that the same swarms return to their natal nesting sites. We examined 23 nesting sites in Nepal, India and Bhutan, on which 587 colonies of $A$. dorsata and A. laboriosa nested. The results showed that the frequency of the periodic mass flights (PMF) performed by the colonies is a good indicator of the status of current colony performance. During the swarming period, both, $A$. dorsata and A. laboriosa issue several swarms. In some colonies, so many bees swarmed out, that those remaining in the maternal colonies did not cover the combs. After the rest of the brood emerged, all the bees of such colonies abscond during the swarming period. Thus, absconding appeared in results of total out swarming. The swarms do not migrate directly to the seasonal alternative nesting sites, but establish new colonies in the areas around. After environmental conditions deteriorate, all the bees with their queens abscond and migrate to alternate seasonal nesting sites. The next season, the swarms do not return to their original reproductive natal sites, but to those sites they occupied the previous season lately, where from they absconded.

Keywords Apis dorsata, Apis laboriosa, migration of bees, swarming, India, Nepal, Bhutan.

\section{INTRODUCTION}

The migratory open air nesting Apis dorsata and Apis laboriosa honeybees migrate at least twice a year (Deodikar et al., 1977; Koeniger and Koeniger, 1980; Reddy, 1983; Venkatesh and Reddy, 1989; Underwood, 1990; Dyer and Seely, 1994; Kahono et al., 1999; Thapa et al., 2000; Lipiński, 2001; Woyke et al., 2001; Liu et al., 2007). The same nesting sites are occupied year after year. Neumann et al. (2000) and Paar et al. (2000) genotyped the migrating A. dorsata bees and showed, that the same swarms return to their natal nesting sites.

The behavior of reproductive swarms of the Asian honey bees after they have left the natal nest is not well studied
(Oldroyd and Wongsiri 2006). Until now, no suggestions were issued, whether the reproductive swarms migrate directly to the alternative seasonal nesting sites, or whether they settle in the area around.

In order to answer this question, we investigated the symptoms of reproductive swarming and absconding in different nesting sites of $A$. dorsata and $A$. laboriosa. This is important to understand the process of swarming, absconding and migration of the migratory $A$. dorsata and A. laboriosa bee.

The aim of our study is not a criticism of the papers of Neumann et al. (2000) and Paar et al. (2000), or the challenge to the results of their research. The present paper is an attempt to answer the questions that arise after reading both the papers. 


\section{MATERIAL AND METHODS}

Data concerning swarming and absconding behaviour of $A$. dorsata and $A$. laboriosa in Nepal and India were collected by us, when we investigated other problems of the biology of these bees (Woyke et al., 2001, 2003, 2004 and 2005a and b). Data concerning Bhutan were collected in 2008 .

We investigated together 23 nesting sites at which 587 colonies nested. At the time, we examined the sites, there were 497 active colonies and 90 abandoned combs. A. dorsata occupied 7 nesting sites with 259 active colonies, and $A$. laboriosa 16 mountain cliffs with 238 active colonies.

A. dorsata colonies in Nepal were observed at 5 nesting sites in Chitwan region, over a period of 7 month 1999/2000 from 7 January to 3 May 1999 and from 11 October 1999 to 15 January, 2000 (Tab. 1). The 132 colonies nested on two water tank towers (Fig. 1) and on two houses on the campus of the Tribhuven University in Rampur, Chitwan $\left(27^{\circ} 39^{\prime}\right.$ $\mathrm{N}, 84^{\circ} 21^{\prime} \mathrm{E}$, alt. $190 \mathrm{~m}$ ) and on a nearby hospital water tank tower in Bharatpur.

A. dorsata colonies in India were observed in Bangalore, over a 10-day period, from 3 to $14 \mathrm{March}, 2002$. The colonies occupied two nesting sites. One with 29 colonies was on the Polytechnic building in the centre of the city. The other with 98 active colonies was on a banyan tree at the campus of the Agricultural University (Fig. 2).

A. laboriosa colonies in Nepal were examined at 4 nesting cliffs in 1998 and 1999 (Tab. 2). In 1998, we observed 61 colonies and in 1999, 146. Three nesting cliffs were situated at Bhote Koshi riverside along the highway from Kathmandu to Kodari at the Nepal - Tibet border. The first cliff was located, in Chale (2752'58" N, $85^{\circ} 54^{\prime} 51^{\prime \prime}$ E, alt. $1178 \mathrm{~m}$ ), near the Chaku village. The second Kodari nesting site was further north near the Kodari waterfall (2756'02" N, 8556'11" E, alt. $1475 \mathrm{~m})$ and the third in Tatopani, near the bridge to China $\left(27^{\circ} 56^{\prime} 51^{\prime \prime} \mathrm{N}, 85^{\circ} 57^{\prime} 06^{\prime \prime} \mathrm{E}\right.$, alt. $1520 \mathrm{~m})$. We examined those nesting cliffs in spring 28 March, 1988 and in the winter 5-6 December, 1999. The fourth nesting cliff was on the Annapurna slope at the Modi Khola riverside near Landrung $\left(28^{\circ} 22^{\prime} \mathrm{N}, 83^{\circ} 50^{\prime} \mathrm{E}\right.$. alt. $\left.1250 \mathrm{~m}\right)$. This was the Landrung cliff of Underwood (1986, 1990) and the Kroja Bhir Landrung of Ahmad et al. (2003), and Joshi et al. (2004). We observed the colonies in winter, during six days, from 27 November to 2 December, 1999.

A. laboriosa colonies in Bhutan occupied 12 nesting cliffs. We examined 92 active nests in autumn 25-29 September 2008. The first nesting site was near the Dochula pass at the altitude of $3108 \mathrm{~m}$. The other nesting cliffs were near Jakar (alt. $2600 \mathrm{~m}$ ), the capital of Bumthang district and in the remote Tang valley (alt. $2800 \mathrm{~m}$ ).

\section{Observations conducted}

We counted the number of active bee colonies and the number of fresh recently abandoned combs at each nesting site. We counted also the number of remains of queen cells at the lower margin of abandoned combs, when the cells were visible. In Chitwan, where $A$. dorsata bees covered the combs, we smoked them from the lower margin of the combs.

At 6 nesting sites occupied by $A$. dorsata and $A$. laboriosa in Nepal and India, we conducted also the whole day uninterrupted observations. We counted the number of periodic mass flights performed by each colony. Location of these sites is presented in the Results chapter.

In Bangalore, India 2002, we determined also the presence or absence of drones during the dusk drone flights. For this, we captured the bees with insect nets and counted the number of drones and worker bees.

With the aid of $12 \times 50$ binoculars, we examined the nesting sites of individual bee colonies from a distance of 5 to $28 \mathrm{~m}$. 


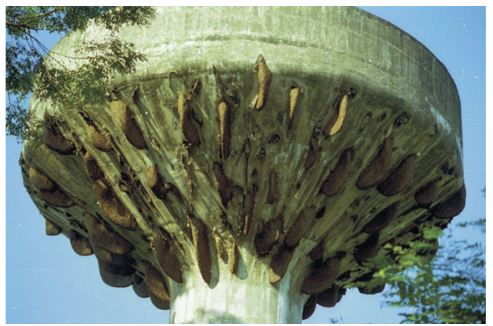

Fig. 1. Water tank tower with $65 \mathrm{~A}$. dorsata nests in Rampur, Nepal.

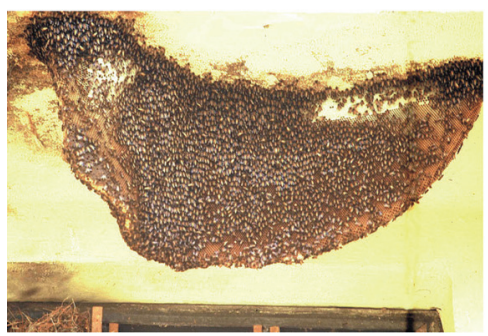

Fig. 3. Colony of $A$. dorsata in which the bees do not cover the comb after issuing several swarms.

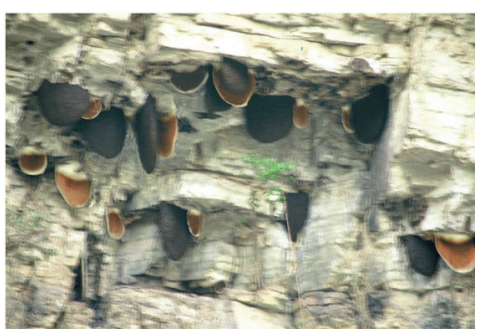

Fig. 5. A. laboriosa nests and some abandoned combs in March 1998 in Nepal.

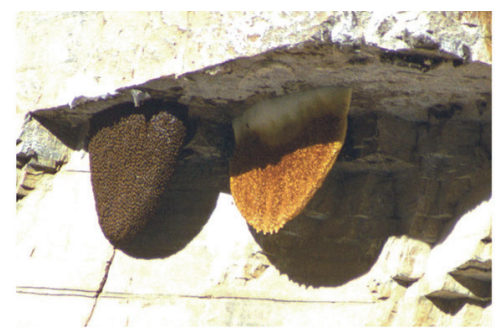

Fig. 7. One normal nest of A. laboriosa and one comb (with remains of queen cells) from which the bees swarmed out in December 1999.

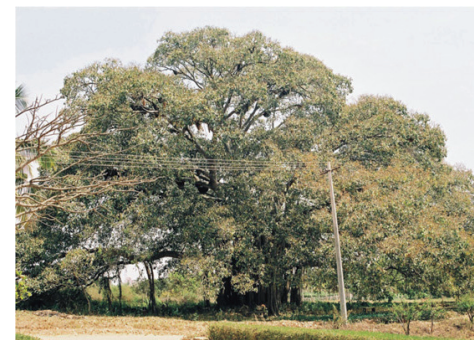

Fig. 2. Banyan tree on which 159 A. dorsata colonies nested in Bangalore, India.

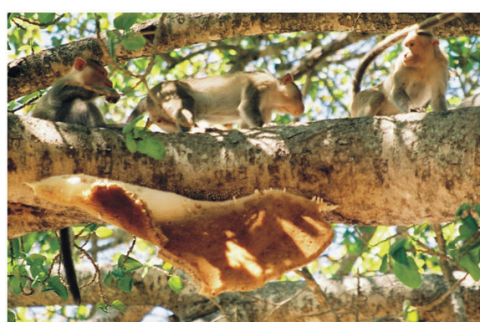

Fig. 4. Abandoned comb of $A$. dorsata with remains of queen cells.

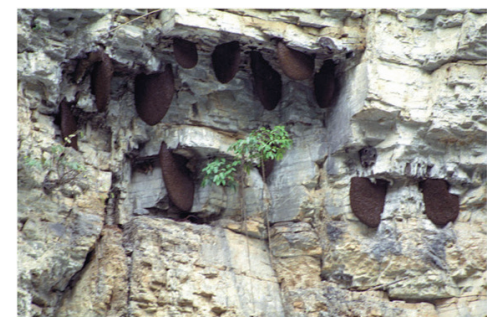

Fig. 6. A. laboriosa nests one year later in December 1999, in Nepal.

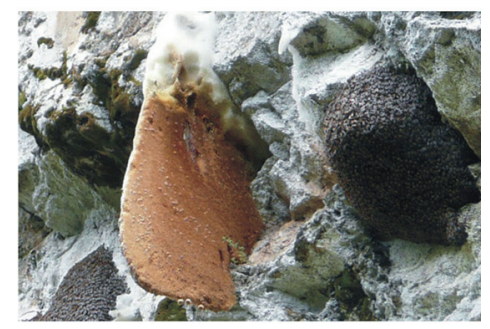

Fig. 8. One comb from which A. laboriosa bees swarmed out and one recently settled swarm in September 2008 in Bhutan. 


\section{RESULTS}

\section{Apis dorsata in Nepal}

During the long period of 7 months observation (October to beginning of May) we were able to monitor the whole nesting season from arriving the swarms, through swarming up to migration to the alternative nesting site (Tab. 1).

New $A$. dorsata swarms arrived at the Chitwan region in October. Eleven, nests were found at 5 nesting sites the 14 October 1999. Next new swarms arrived, but also some migrated after several days. The 22 November 1999, 37 nests were found at those locations. Mustard started flowering at the beginning of December. Many fields around turned yellow of the flowers. December was the main nectar flow. The 7 December 1999, 106 nests were found and no nests were abandoned. Eight swarms arrived in our presence. 20 December 1999, the highest number of 132 colonies nested here (Fig. 1). The colonies reached the stage of the maximal development in December. In January, they started to swarm. They built queen cells to rear new queens. The queen cells were inside characteristic cones of bees hanging down at the lower margin of the nests. We found $3,4,6,8,9,12$ and 13 queen cells in seven nests. Shortly before the new queen emerged, the old queen swarmed together with part of the worker bees. Next the colonies issued several afterswarms. Four swarms swarmed in our presence.
The swarms did not cluster nearby, but flew away from the nesting site. After issuing several swarms, so many worker bees have left some nests, that the remaining bees covered only part of the combs (Fig. 3). The honey stores at the top of the combs were not covered by the bees. Remains of about 10 queen cells were visible along the lower margin of the comb (Fig. 3).

After all workers emerged from the rest of brood, the rest of the maternal colonies absconded few days later. We point up, that the rest of the colonies abandoned the combs not because the environmental food resources deteriorated. In reality, the nectar flow was favourable. However, the remaining bees were not able to cover the combs. The other colonies, which after swarming covered the combs, developed afterwards and grew in strength. In April and May, the drought started. The food resources exhausted, and all the colonies absconded and migrated to seasonal alternative nesting sites.

At the beginning of the nesting season, 18 October, the colonies performed on average 1 periodic mass flight per colony per day (PMF/col./day). At the stage of maximal colony development, of the colonies, 14 December, they performed 2.2 PMF/colony/per day. Later, when the food resources deteriorated, 2 April, they performed less - 1.7 PMF/col./day. Thus the $\mathrm{PMF} / \mathrm{col} . /$ day is a quite good indicator of the colony performance.

Table 1 .

Nesting sites of Apis dorsata in Nepal and India

\begin{tabular}{|c|c|c|c|c|c|c|}
\hline \multicolumn{3}{|c|}{ Nesting sites } & \multicolumn{4}{|c|}{ Numbers } \\
\hline No. & Name & $\begin{array}{c}\text { Altitude } \\
\mathrm{m}\end{array}$ & $\begin{array}{l}\text { Active } \\
\text { colonies }\end{array}$ & $\begin{array}{c}\text { Abandoned } \\
\text { combs }\end{array}$ & Total & $\begin{array}{c}\text { Queen cell } \\
\text { remains }\end{array}$ \\
\hline \multicolumn{7}{|c|}{ Nepal, 7 January - 31 May 1999, and 11 October 1999 - 15 January, 2000.} \\
\hline $1-5$ & Chitwan & 190 & 132 & $(56)^{\star}$ & 132 & $2-13$ \\
\hline \multicolumn{7}{|c|}{ India, 3 - 14 March 2002} \\
\hline 6 & Polytechnic & 920 & 29 & 0 & 29 & \\
\hline 7 & $\begin{array}{c}\text { Banyan } \\
\text { tree }\end{array}$ & 920 & 98 & 61 & 159 & $1-9$ \\
\hline \multirow{2}{*}{\multicolumn{3}{|c|}{\begin{tabular}{l|l} 
Total India & \\
Overall Nepal + India
\end{tabular}}} & 127 & 61 & 188 & \\
\hline & & & 259 & 61 & 320 & \\
\hline
\end{tabular}

* 56 abandoned combs present 31 May, of the total 132 active colonies present here in December. 
It is worth noting, that the swarming period occurred during favourable food resources conditions, 2 months before the drought started, when the colonies migrated to the seasonal alternative nesting sites.

\section{Apis dorsata in India}

On the balcony of the Polytechnic building in Bangalore, 21 colonies nested on the $3^{\text {rd }}$ March 2002. That number increased to 29 colonies, nine days later (Tab. 1). Seven swarms arrived in our presence. The colonies performed $1.8 \mathrm{PMF} / \mathrm{col} . /$ day, the $3^{\text {rd }}$ March, and as many as $2.8 \mathrm{PMF} / \mathrm{col}$./day, six days later $\left(9^{\text {th }}\right.$ March). This was the time of arriving of new swarms and growing of the colonies.

The $10^{\text {th }}$ March, no drones or very few of them (avg. 1.3\% of 1858 caught bees) were present in 15 arrived swarms. This indicates, that the arriving swarms were not reproductive ones, but absconded from the previous nesting site and migrated due to unfavourable food resources.

The area around the banyan tree site at the Agriculture University had scarce food resources. The fields were harvested. At the banyan tree, 98 active $A$. dorsata colonies nested in the $4^{\text {th }}$ March 2002 (Fig. 2). In addition, we found 45 empty recently abandoned combs (Fig. 4) and 16 remnants of fallen combs.
Thus, 159 colonies nested here earlier. Of the 21 empty combs examined, 8 had from 1 to 9 remains of empty queen cells. Nine days later (13 March), 87 colonies remained - 11 absconded. Six swarms absconded in our presence. Thus, the remains of queen cells were remnants from the swarming period.

The colonies performed during the 10-day period on average only $0.11 \mathrm{PMF} / \mathrm{col} . /$ day. This was the lowest number of $\mathrm{PMF} / \mathrm{col}$./day, ever observed by us. Some colonies did not perform any PMF during several days. Evidently, the colonies were not swarming, but emigrated due to scarce food resources.

The above shows, that during arriving period, when the colonies produced the brood, they performed 25 times more PMF/col./day (2.8) than colonies preparing to migrate $(0.11)$ when they stopped to rear new brood.

\section{Apis laboriosa in Nepal}

In Nepal, we investigated 4 nesting sites, at which $171 \mathrm{~A}$. laboriosa colonies nested, of which 146 nests were active (Tab. 2).

At the lowest located Chale nesting cliff (alt. $1178 \mathrm{~m}$ ), 43 active colonies nested in the spring, 28 March 1998 (Fig. 5). Additionally, as many as 14 recently abandoned (fresh) combs were present.

This indicates, that together 57 colonies nested here earlier. On the lower margin of

Table 2 .

Nesting sites of Apis laboriosa in Nepal 1998 and 1999

\begin{tabular}{|c|c|c|c|c|c|c|}
\hline \multicolumn{3}{|c|}{ Nesting sites } & \multicolumn{4}{|c|}{ Number } \\
\hline No. & Name & $\begin{array}{c}\text { Altitude } \\
\text { m }\end{array}$ & $\begin{array}{l}\text { Active } \\
\text { colonies }\end{array}$ & $\begin{array}{l}\text { Abandoned } \\
\text { combs }\end{array}$ & Total & $\begin{array}{l}\text { Queen cell } \\
\text { remains }\end{array}$ \\
\hline \multicolumn{7}{|c|}{ Nepal, Spring, 28 March 1998} \\
\hline 2 & Chale & 1178 & 43 & 14 & 57 & $4-8$ \\
\hline 3 & Kodari & 1475 & 4 & 1 & 5 & 3 \\
\hline 4 & Tatopani & 1520 & 14 & & 14 & \\
\hline Total & & & 61 & 15 & 76 & \\
\hline \multicolumn{7}{|c|}{ Nepal, Winter, Annapurna 27 Nov.- 2 Dec, other sites 5-6 December 1999} \\
\hline 1 & Annapurna & 1250 & 16 & 1 & 17 & \\
\hline 2 & Chale & 1178 & 53 & 4 & 57 & $2,4,7, ?^{*}$ \\
\hline 3 & Kodari & 1475 & 6 & 2 & 8 & 3,4 \\
\hline 4 & Tatopani & 1520 & 10 & 3 & 13 & $?, ?, ?$ \\
\hline Total & & & 85 & 10 & 95 & \\
\hline \multicolumn{2}{|c|}{ Total both years } & & 146 & 25 & 171 & \\
\hline
\end{tabular}

?* indicates, the queen cells were not clearly visible. 
the abandoned combs, the remains of 4-8 empty queen cells were present. Evidently, the colonies at this cliff swarmed in March. It is worth noting that the last swarms left the combs not in result of reproductive division of the colonies, but all the bees of the maternal colony absconded together with the last new queen.

The next year, December $5^{\text {th }}$ and $6^{\text {th }}$, 1999, 53 active colonies nested here in winter (Fig. 6). Additionally, 4 recently (fresh) abandoned combs were present here. Thus, together 57 colonies nested here earlier. This show, that exactly the same number of swarms returned to this nesting cliff, the next year.

The remains of open queen cells were visible along the lower margin of the abandoned combs. On the largest comb, the remains of 7 queen cells were present. The appearance of those cells indicated that new queens emerged at least from 5 cells (Fig. 7). All those cells were not damaged by the bees. This suggests that this colony swarmed several times. At the lower margins of two smaller abandoned combs the remains of 2 and 4 queen cells were found. Thus, the colonies swarmed totally out of the combs already in the beginning of December. Some other colonies could have also swarmed, but the rest of the maternal colony remained at the combs. Although the colonies swarmed already in December, it is doubtful to imagine, they migrated so early in the year to higher elevation in the mountains. Rather, they settled around in similar elevation, where environmental conditions were favorable.

The two-day average of PMF/col./ day $=0.72$. This was 7 times more than during the migration period of $A$. dorsata (0.11 PMF/col./day). Evidently, the colonies did not prepare to abandon the combs and to migrate.

At both nesting cliffs, Kodari (alt. $1475 \mathrm{~m}$ ) and Totapani (alt. $1520 \mathrm{~m}$ ), together $4+14=18$ active colonies nested here March 28, 1998. Additionally, 1 abandoned comb was found. Thus, together 19 colonies nested here earlier. The next year $5^{\text {th }}-6^{\text {th }}$ December, 1999 , $6+10=16$ active colonies nested here. Additionally, $2+2=4$ recently abandoned combs were found, on which remains of 3 and 4 queen cells were present along the lower margins of the combs. Thus, together 20 colonies nested here the last year. Hence, only 1 more swarm settle here the next year.

Nesting sites of Apis laboriosa in Bhutan 25-29 September 2008

\begin{tabular}{||c|c|c|c|c|c|c||}
\hline \hline \multicolumn{3}{|c|}{ Nesting sites } & \multicolumn{4}{c||}{ Number } \\
\hline No. & Name & $\begin{array}{c}\text { Altitude } \\
\mathrm{m}\end{array}$ & $\begin{array}{c}\text { Active } \\
\text { colonies }\end{array}$ & $\begin{array}{c}\text { Abandoned } \\
\text { combs }\end{array}$ & Total & $\begin{array}{c}\text { Queen cell } \\
\text { remains }\end{array}$ \\
\hline 1 & Dochula & 3108 & 20 & 0 & 20 & \\
\hline 2 & Jakar 2 & 2600 & 7 & 0 & 7 & \\
\hline 3 & Jakar 3 & 2600 & 8 & 1 & 9 & $?^{*}$ \\
\hline 4 & Jakar4 & 2600 & 30 & 0 & 30 & \\
\hline 5 & Bridge & 2600 & 2 & 0 & 2 & \\
\hline 6 & Tang6 & 2800 & 5 & 0 & 5 & 2 \\
\hline 7 & Tang7 & 2800 & 5 & 0 & 5 & 4 \\
\hline 8 & Tang 8 & 2800 & 6 & 1 & 7 & 3 \\
\hline 9 & Tang9 & 2800 & 3 & 1 & 4 & \\
\hline 10 & Tang 10 & 2800 & 1 & 1 & 2 & \\
\hline 11 & Tang 11 & 2800 & 2 & 0 & 2 & \\
\hline 12 & Tang 12 & 2800 & 3 & 0 & 3 & \\
\hline Total & & & 92 & 4 & 96 & \\
\hline \hline
\end{tabular}

?* indicates the queen cells were not clearly visible. 
At Annapurna nesting cliff (alt. $1250 \mathrm{~m}$ ), 16 active $A$. laboriosa colonies nested during our observation from 27 November to 2 December 1999. No fresh abandoned comb was found. Apparently, the colonies did not yet start to swarm or migrate.

The five-days mean of PMF/col./day $=0.55$. This was lower than in winter at the Chale cliff (PMF/col./day $=0.76)$, where the colonies started to swarm. However, it was 5 times higher than during the migration period of $A$. dorsata $(\mathrm{PMF} / \mathrm{col} . / \mathrm{day}=0.11)$. This, indicates that the colonies at the Annapurna cliff were active in rearing some brood in December.

\section{Apis laboriosa in Bhutan}

We examined 12 nesting cliffs with 79 active $A$. laboriosa colonies in autumn 25-29 September 2008 (Tab. 3).

The first nesting cliff near the Dochula pass was at the altitude of $3108 \mathrm{~m}$, the highest at which we examined the nesting sites. We found here 20 active $A$. laboriosa colonies. No abandoned combs were noticed. Apparently, the colonies at this elevation, neither swarmed nor emigrated recently.

The 4 other nesting sites (Nos 2-5) were near Jakar, the capital of Bumthang district and 7 in the remote Tang valley (Nos 6-12). The area around turned bright pink with buckwheat flowers, although it was the end of September. In addition to the 59 active colonies at the Tang cliffs, we found here 4 fresh recently abandoned combs. Along the lower margin of those combs, the remains of 3-4 empty queen cells were present (Fig. 8). This means that the colonies swarmed recently several times.

The last swarm which abandoned each comb was not the result of reproductive division of the colony, but all the bees absconded together with the queen.

We found also recently settled swarms. They were broad and shallow (Fig. 8). The combs were not yet built. Within all the colonies, about 20 were very small. We think, those were the new colonies arising from the recently settled swarms. This would indicate that the new swarms did not migrate to the alternative seasonal nesting site, butt settled in the area around, where reach food resources were present.

The 5 colonies at the Tang valley, near the Tang village (No. 6) performed the 24 September, 13 periodic mass flights, it is 2.6 PMF/col./day. This is much and indicates the colonies were in good conditions and did not prepare to migrate.

Swarming at the end of September at altitude of $2800 \mathrm{~m}$ was rather unexpected. However, the reach buckwheat nectar flow enabled this.

\section{DISCUSSION}

New swarms arriving to the nesting site may be determined as reproductive or migratory ones, by the presence or absence of drones, respectively.

We showed that the (Periodic Mass Flight) $\mathrm{PMF} / \mathrm{col} . /$ day is a good indicator of the status of the present biological characteristics of the colonies of $A$. dorsata and $A$. laboriosa.

The behavior of reproductive swarms of A. dorsata and A. laboriosa bees, after they have left the natal nest, is not well studied (Oldroyd and Wongsiri, 2006, p. 94). However, the authors suggest that the process is similar to that of A. mellifera.

We found three causes, the migratory $A$. dorsata and A. laboriosa abandoned the combs.

1. Typical reproductive swarming with division of the colony.

2. Absconding of the rest of the maternal colony during favourable swarming period. We call this, total out swarming.

3. Preparatory absconding (migration) after environmental conditions deteriorate.

ad 1./ We showed here that the colonies issue several reproductive swarms during the swarming period. The old queen leaves the colony with the prime swarm. New emerged queens are present in the afterswarms. The maternal part of the colony remains on the comb. We did not noticed, the swarms settled near the parental colonies, like it happens in A. mellifera. The swarms fly away from 
the natal nesting sites. No suggestions were issued until now, whether the reproductive swarms migrate directly to the alternative seasonal nesting site, or whether they settle in another nesting sites around. We found, during the swarming period, recently settled swarms and new small colonies at the nesting sites around. It is also hard to believe that already in December, when some $A$. laboriosa colonies issue reproductive swarms at the lower elevation, the swarms migrate to the seasonal alternative nesting sites at a higher elevation in the mountains. During the swarming period, the environmental food conditions are favourable. No environmental pressure forces the reproductive swarms to leave the area. This suggest that reproductive swarms spread at the area around, build here the combs and establish new colonies. They do not migrate to the seasonal alternative nesting sites where the environmental conditions are still unfavorable.

ad 2./ We showed that after the colonies issued several afterswarms so few bees remained in some maternal colonies, that they did not cover the combs. The bees were not able to protect the remaining honey stores and the whole combs. Probably they were not able to create the microclimate to rear the brood. After workers emerged from the rest of the brood, all the bees with the new queen (probably virgin) abscond. Lipiński (2001) classifies this as atypical absconding. Thus, there are two types of reproductive swarming.

1./ Normal reproductive swarming, when after issuing some swarms, the rest of the maternal colony remains on the comb.

2./ Total reproductive out swarming, when after issuing several swarms also the rest of maternal colony swarm up and abandon the combs.

Hepburn (2011, p. 135) does not mention, that the reason for absconding could be the low number of bees, which remains at the comb after the last reproductive swarms departed. Thus, the number of fresh abandoned combs found at the nesting site during the swarming period does not indicate neither the number of colonies, which swarmed, nor the rate of swarming. The number of issued swarm is higher, but not all the maternal colonies which issued the swarms abscond afterward. The absconded swarms establish new small colonies at the nesting sites around. Such total out swarming behavior does not occur in the cavity nesting bee A. mellifera. After issuing several swarms, A. mellifera bees of the weakened maternal colonies destroy the remaining queen cells and do not abscond.

Thus, at the two points above, the behaviour of the migratory $A$. dorsata and A. laboriosa bees differ from the cavity nesting A. mellifera. However, additional unfavorable stimuli, could cause the Africanized (and probably the African) bees A. m. scutellata to abscond. Winston et al. (1979, p. 92) report, that the only colonies which absconded during the swarming period were the un-shaded ones, located in full sun. The smaller number of bees could not maintain the right temperature of the brood nest.

3./ After the environment condition and the food resources deteriorate, the bees are forced to abandon the nest, which is called prepared absconding or migration. The bees stop brood rearing and all the bees with their queens abscond and as migratory swarms migrate to the seasonal alternative nesting sites, where the environmental conditions are favourable. At the end of the season at the alternative site, when the conditions deteriorate there, the bees return to the previous nesting sites.

The question is, whether the reproductive swarms of the previous season and especially the first ones with the old queen, return to their original reproductive natal sites. The previous season, the reproductive swarms established already new colonies in other nesting sites around their natal nesting sites. Swarming and creation of new nests brakes the colony unity with maternal colony and the natal nest site. At the end of the season, prepared absconding occurs in all the colonies. All this suggest that the next season the swarms do not return to their original reproductive natal nesting 
sites, but to the sites they occupied at the end of the previous season, where from they migrated. According to Woyke et al. (2012), the colonies select as nesting sites mountain cliffs with light unweathered surface.

If all swarms returned to their natal site, then more swarms should return, than the number of colonies, which nested here the previous season. However, we found in Nepal as well as Liu (2007) in Boreneo, that similar number returned. This would support the suggestion that reproductive swarms do not return to their original reproductive natal nesting site. However, swarming should increase the global number of migratory bee colonies. In the contrary, the number of colonies of those bees decreases in many countries. Mostly, this is the effect of honey hunting. However, Tshering (2008) reports, that in Bhutan, where honey hunting is not practices, the number of $A$. laboriosa colonies is increasing.

Of course also simple absconding exists (Hepburn, 2011), which is the reaction to disastrous events. We did not investigate this phenomenon.

Concerning the papers of Neumann et al. (2000) and Paar et al. (2000) about returning of the swarms to the natal site, it is not known, whether the bees for DNA analysis were collected before, or after, the swarming season. If they were collected after the swarming season, and the bees did not swarm in the alternative seasonal new nesting site, they could return the next season to the previous location with the same queen. However, if the test bees were collected before the swarming season, the old queen swarmed out with the first swarm and braked the unity with the nesting site. A new queen remained in the original colony. After migration, the next season, the swarm returned with the daughter queen. However, both reports, show that out of 22 individual nesting sites, the swarms returned to 2 sites with the old queen not only the second, but also the third season. This would mean, that for two years, either those colonies did not swarm at both places (the old and the new one), or the old queens did not depart with the first swarms, but remained in the maternal colonies. Such contrary results in fundamental behavior of the honeybee, seem incredible. Thus, further investigations are necessary.

\section{CONCLUSIONS}

1. During swarming season, A. dorsata and A. laboriosa colonies issue several swarms. The reproductive swarms leave the natal nesting sites and settle in other ones in the areas around. The swarming phenomenon breaks the colony unity of the swarms with their maternal colony and with their natal sites.

2. In some swarming colonies, so many bees swarm out, that the remaining ones, do not cover the combs. Such weakened maternal colonies abscond during the swarming period after the brood emerges. Thus, total out swarming occurs.

3. The food resources are favorable during the swarming period. Thus, there is not environmental pressure to change the living conditions, by the swarms. Therefore, reproductive swarms and those totally out swarming ones, do not migrate directly to the seasonal alternative nesting sites, but establish new colonies in the nesting sites around.

4. After the environmental condition deteriorate, the bees stop brood rearing and prepare to abscond. All bees with their queens migrate to a seasonal alternative nesting site.

5. When the conditions deteriorate at the alternative nesting sites, the swarms return the next season to the nesting sites they occupied-lately, where from they migrated, and not to their original reproductive natal sites.

\section{ACKNOWLEDGEMENTS}

We would like to thank the Government of Bhutan, which enabled us to come to Bhutan in 2008, to participate in the $2^{\text {nd }}$ International Beekeeping Congress, a tribute to coronation of $5^{\text {th }}$ Druk Gyalpo and provided us possibilities to conduct 
the studies afterwards. We would like to thank also Dr D. Ghalay from the Ministry of Agriculture, Thimphu, Bhutan for help during the investigation in Bhutan and Dr S. R. Joshi from the ICINOD in Kathmandu, Nepal, for providing some information concerning the nesting cliffs in Nepal. We thank also the Dabur Company India/Nepal for providing facilities during our stay in Nepal. We thank also dr hab. Zbigniew Lipiński from the Institute of Animal Reproduction and Food Research of Polish Academy of Sciences, Olsztyn, Poland for valuable suggestions concerning the manuscript, and the referee Prof. dr hab. Jerzy Paleolog from the University of Life Sciences, in Lublin, Poland for corrections and issuing valuable suggestions concerning the final version of the manuscript.

\section{REFERENCES}

Ahmad F., Joshi S. R., Gurung M. B. (2003) -The Himalayan cliff bee Apis laboriosa and the honey hunters of Kaski. ICIMOD; Kathmandu, Nepal. pp.52.

Deodikar G. B., Ghatge A. L., Phadke R. P., Mahindre D. B., Kshirsagar K. K., Muvel K. S., Thakar S. S. (1977) - Nesting behaviour of Indian honeybees. III. Nesting behaviour of Apis dorsata Fab. Indian Bee J., 39: 1-12.

Dyer F. C., Seeley T. D. (1994) - Colony migration in the tropical honey bee Apis dorsata. (Hymenoptera: Apidae). Insectes soc., 41: 129-140.

Hepburn H. R. (2011) - Absconding, migration and swarming. in Hepburn H. R., Radloff S. E. (Ed.) Honeybees of Asia, Springer, Heidelberg, Dordrecht, London, New York, pp.113-158.

Joshi S. R., Ahmad F., Min B., Gurung M.B. (2004) - Status of Apis laboriosa populations in Kaski district, western Nepal. J. Apic. Res., 43: 176-180.

Kahono S., Nakamura K., Amir M. (1999)-Seasonal migration and colony behavior of the tropical honeybee Apis dorsata F. (Hymenoptera: Apidae). Treubia, 31: 283-297.
Koeniger N., Koeniger G. (1980) Observations and experiments on migration and dance communication of Apis dorsata in Sri Lanka. J. Apic. Res., 19: 21-34.

Lipiński Z. (2001) Essence and mechanism of nest abandonment by honeybees swarms. Blenam, Olsztyn pp. 291.

Liu F., Roubik D.W., He D., Li J. (2007) - Old comb for nesting site recognition by Apis dorsata? Field experiments in China. J. Insect. Soc., 54: 424-426.

Neumann P., Koeniger N., Koeniger G., Tingek, S., Kryger P., Moritz R. F. A. (2000) - Home-site fidelity in migratory bees. Nature, 406: 474-475.

Oldroyd B. P. (2006) - Asian honey bees. Harvard University Press, Cambridge, Massachusetts, and London, England pp. 340

Paar J., Oldroyd B. P., Kastberger G. (2000) - Giant honeybees return to their nest sites. Nature, 406: 475.

Reddy C. C. (1983) - Studies on the nesting behaviour of Apis dorsata F. In Proc. $2^{\text {nd }}$ Int. Conf. Apic. Trop. Clim., New Delhi: 391-397.

Thapa R.,Wongsiri S., Oldroyd B. P., Praw an S. (2000) - Migration of Apis dorsata in northern Thailand. In Proc. $4^{\text {th }}$ Asian Apic Assoc. Conf., Kathmandu: 39-43.

Tshering G. (2008) - Status of Apis laboriosa in Bhutan - Himalayan cliff bee in Bhutan. In $2^{\text {nd }}$ International Beekeeping Congress, Thimphu, Bhutan 19-21 August 2008. p. 24.

Underwood B. A. (1986) - The natural history of Apis laboriosa Smith in Nepal. MS Thesis, Cornel Univcersity, Ithaca, USA pp. 88.

Underwood B. A. (1990) - Seasonal nesting cycle and migration patterns of the Himalayan honeybee Apis laboriosa. Natl. Geogr. Res., 6: 276-290.

Venkatesh G., Reddy C. C. (1989) - Rates of swarming and absconding in the giant honey bee, Apis dorsata F. Proc., Indian Acad. Sci., 98: 425-430.

Winston M. L., Otis G. W., Taylor O. R. Jr. (1979) - Absconding behaviour of the Africanized honeybee in south America. J. Apic. Res., 18: 85-94. 
Woyke J., Wilde J., Wilde M. (2001)

- Swarming, migration and absconding of Apis dorsata colonies. In Proceedings of the $7^{\text {th }}$ International conference on apiculture in tropical climates, Chiang Mai: 183-188.

Woyke J., Wilde J., Wilde M. (2003) - Periodic mass flights of Apis laboriosa in Nepal. Apidologie, 34: 121-128.

Woyke J., Kruk C., Wilde J., Wilde M. (2004) - Periodic mass flights of the giant honey bee Apis dorsata. J. Apic. Res., 43: 180-185.

Woyke J., Wilde J., Reddy C., Nagaraja N. (2005a) - Periodic mass flights of the giant honeybee Apis dorsata in successive days at two nesting sites in different environment conditions. J. Apic. Res., 44: 140-149.
Woyke J., Wilde J., Wilde M., Reddy C., Cervancia C. (2005b) Workers often predominate in dusk 'drone flights' of the giant honey bee Apis dorsata. J. Apic. Res., 44: 130-132.

Woyke J., Wilde J., Wilde M. (2012) Which mountain cliffs do Apis laboriosa honey bees select as nesting sites and why? J. Apic. Res., 51: 193-203.

\title{
RÓJKA I WĘDRÓWKA PSZCZÓŁ APIS DORSATA I APIS LABORIOSA W INDIACH, NEPALU I BHUTANIE
}

\author{
Woyke J., Wilde J., Wilde M.
}

$\mathrm{S} t \mathrm{r}$ e s z c z e $\mathrm{n}$ i e

Wolno gniazdujące azjatyckie pszczoły Apis dorsata i Apis laboriosa wędrują co najmniej dwa razy w roku. Genotypowe badania DNA wykazały, że roje wracają do swych macierzystych miejsc gniazdowania. Zbadaliśmy 23 miejsc gniazdowania w Nepalu, Indiach i Bhutanie, na których gniazdowało 587 rodzin $A$. dorsata i A. laboriosa. Stwierdziliśmy, że okresowe masowe loty (ang. skrót PMF) wykonywane przez te pszczoły, są dobrym wskaźnikiem stanu rodzin pszczelich. Zaobserwowaliśmy, że w okresie rójki, kilka rojów wyrajało się z macierzaków $A$. dorsata i A. laboriosa. Z niektórych macierzaków wyrajało się tak wiele pszczół, że pozostałe nie pokrywały plastrów. Po wygryzieniu się robotnic z resztek czerwiu, wszystkie pszczoły z takich rodzin opuszczały plastry w okresie rójki. Tak więc u badanych pszczół, zdarza się, że wszystkie pszczoły opuszczają plastry, na skutek rójki. Zjawisko takie nie zachodzi u gniazdujących w pomieszczeniach pszczół A. mellifera. Roje Apis dorsata i Apis laboriosa nie wędrują bezpośrednio do sezonowych alternatywny miejsc gniazdowania, lecz osiedlają się w innych miejscach w okolicy, budują tam plastry i tworzą nowe rodziny. Rójka i tworzenie nowych gniazd zrywa poczucie jedności z macierzakami. Po pogorszeniu się warunków środowiskowych i braku źródeł pokarmu wszystkie pszczoły porzucają plastry i wędrują (migrują) do alternatywnych sezonowych miejsc gniazdowania. Gdy tam warunki środowiskowe i żywnościowe pogorszą się, pszczoły porzucają tam plastry i wędrujące roje wracają. Jednak ubiegłoroczne nowe roje nie powracają do miejsc gniazdowania macierzaków, lecz do swoich miejsc gniazdowania, z których wyemigrowały w ubiegłym sezonie.

Słowa kluczowe: Apis dorsata, Apis laboriosa, wędrówki pszczół, rójka, India, Nepal, Bhutan. 